\title{
Investigational Product Device Maintenance Log
}

National Cancer Institute

\section{Source}

National Cancer Institute. Investigational Product Device Maintenance Log. NCI

Thesaurus. Code C125436.

A record or log of activities documenting the quality and condition of medical devices used in clinical trials. 